\title{
The development of a reliable and valid instrument to measure the osteoporosis- related knowledge: validation of the Hungarian version of Osteoporosis Knowledge Assessment Tool (OKAT)
}

Peter Tardi ${ }^{1,2^{*}}$, Brigitta Szilagyi ${ }^{2}$, Alexandra Makai ${ }^{1}$, Monika Gyuro ${ }^{3}$, Pongrac Acs ${ }^{1}$, Melinda Jaromi ${ }^{1}$, Balint Molics ${ }^{1+}$ and Marta Hock ${ }^{1+}$

\begin{abstract}
Background: Osteoporosis is one of the most common chronic musculoskeletal diseases. Osteoporosis-related knowledge is an important contributor in to prevent osteoporosis. There is no validated reliable questionnaire to measure the knowledge in Hungary. The aim of the study was to validate the Osteoporosis Knowledge Assessment Tool (OKAT) Hungarian version.

Methods: The research was a randomized validation study of a new Hungarian language instrument. The questionnaire was administered to 557 randomly selected healthy women (age between 25 and 44 years) from December 2018 to July 2019 in Baranya county, Hungary. The reliability was examined by the Flesch reading ease and McNemar's test. We examined item discrimination and item-total correlations, inter-item consistency (Cronbach's alpha coefficient) and principal component factor analysis.
\end{abstract}

Results: Significant differences $(p<0.001)$ were reported between total scores and the age categories. Significant $(p<0.001)$ correlation $(r=0.25)$ was found between the education level and the knowledge. Significantly $(p<0.001)$ higher knowledge were found in health care profession (14.53 \pm 3.58$)$ than the non-health care profession $(9.99 \pm 4.04)$. Participants with osteoporosis or fracture in family history had better knowledge $(p<0.001)$. Flesch reading ease was 44, the questionnaire had a Ferguson's sigma of 0.94 and a Cronbach's alpha of 0.81 . There were no negative inter-item correlations psychometric properties of the OKAT, all items had more than $70 \%$ of correlations $(p<0.001)$.

Conclusions: The Hungarian version of the Osteoporosis Knowledge Assessment Tool is a reliable and objective questionnaire to measure women's knowledge in Hungary.

Keywords: Osteoporosis-related knowledge, Public health, Health education, Patient education, Medical education

\footnotetext{
*Correspondence: peter.tardi@etk.pte.hu

${ }^{\dagger}$ Balint Molics and Marta Hock contributed equally to this work.

'University of Pécs, Faculty of Health Sciences, Institute of Physiotherapy and

Sport Science, Pécs, Hungary

${ }^{2}$ University of Pécs, Faculty of Health Sciences, Doctoral School of Health

Sciences, Pécs, Hungary

Full list of author information is available at the end of the article
}

(c) The Author(s). 2021 Open Access This article is licensed under a Creative Commons Attribution 4.0 International License, which permits use, sharing, adaptation, distribution and reproduction in any medium or format, as long as you give appropriate credit to the original author(s) and the source, provide a link to the Creative Commons licence, and indicate if changes were made. The images or other third party material in this article are included in the article's Creative Commons licence, unless indicated otherwise in a credit line to the material. If material is not included in the article's Creative Commons licence and your intended use is not permitted by statutory regulation or exceeds the permitted use, you will need to obtain permission directly from the copyright holder. To view a copy of this licence, visit http://creativecommons.org/licenses/by/4.0/ The Creative Commons Public Domain Dedication waiver (http://creativecommons.org/publicdomain/zero/1.0/) applies to the data made available in this article, unless otherwise stated in a credit line to the data. 


\section{Background}

Osteoporosis is a disease affecting the structure of the skeleton as a result low bone mineral density and microarchitectural deterioration of bone tissue is generated. Due to the bone mineral density reduction the risk of fragility increases and because of the muscle mass and muscle strength deterioration the risk of falls also increases which results in higher risk of fractures [1]. It is widely accepted hat this disease is associated with impairments of quality of life following fracture, and increased mortality [2-5].

Nowadays it is becoming a major public health problem particularly in postmenopausal women as the incidence of this disease is getting higher and higher. Worldwide more than 200 million people live with osteoporosis that causes 8.9 million fractures per year [6, 7]. In the United States of America 10.2 million adults were diagnosed with osteoporosis and 43.4 million adults with low bone mass. In terms of gender 8.2 million women and 2.0 million men were diagnosed with osteoporosis and 27.3 million women and 16.1 million men had low bone mass. In Europe the problem is also significant, 22 million women and 5.5 million men were estimated to have osteoporosis and 3.5 million new fragility fractures were sustain per year. In Europe the economic burden of the diagnoses and the treatment of the prior fragility fractures was about $€ 37$ billion $[6,8]$. In Hungary $10 \%$ of the total population is suffering from osteoporosis [9].

Osteoporosis is a progressive musculoskeletal disease, not curable, but can be slowed down, that is why prevention could be the best therapeutic option [10]. Nowadays the patient education is one of the most important part of the prevention. There is evidence suggesting that osteoporosis knowledge is one contributor to osteoporosis preventive behaviour [11-14]. The most important preventive strategies are increasing the level of physical activity at all ages, cessation of smoking, reduction of alcohol consumption, adequate dietary calcium and vitamin D intake [15-19]. Several studies have reported different levels of osteoporosis knowledge in random, population-based samples and these cross-sectional studies have found relation between levels of osteoporosis knowledge and osteoporosis preventive behaviours [20-22]. Prospective studies have been conflicting with some studies demonstrating increases in osteoporosis knowledge and concurrent improvements in osteoporosis preventive behaviours [23-27]. Various tools are available to assess women's knowledge about osteoporosis like Facts on Osteoporosis Quiz (FOOQ), the Osteoporosis Questionnaire (OPQ), The Osteoporosis Knowledge Test (OKT) and the Osteoporosis Knowledge Assessment Tool (OKAT). Measurement of osteoporosis knowledge is itself problematic and this may be one of the reasons for the variation in the results of the studies described previously. Regardless of the instrument used, serious lack of knowledge was demonstrated on osteoporosis and its related risk factors [28, 29].

Nothing is known about Hungarian women's health beliefs and their preventative behaviours regarding osteoporosis, because there were no studies about that and there are no valid and reliable tools to measure osteoporosisrelated knowledge and beliefs for Hungarian-speaking women. Determining their knowledge, beliefs and behaviours about osteoporosis could be helpful in developing effective education interventions and guiding public health programs for osteoporosis prevention. We specifically would like to have an instrument in Hungarian to measure the knowledge about osteoporosis in that age when the disease is preventable and with healthy lifestyle the knowledge can protect them against osteoporosis in later life.

The Osteoporosis Knowledge Assessment Tool (OKAT) was developed by Winzenberg et al. [30] and validated to Arabic language by Sayed-Hassan and Bashour [10] to measure the knowledge in women between 25 and 44 year age ranges.

Therefore, the aim of this study was to describe the validation of a method in Hungarian to measure the osteoporosis knowledge in a population-based random sample of 25-44-year-old women.

\section{Materials and methods Validation process}

The study was carried out in two phases in Pécs, Baranya County, South-western part of Hungary. In the first phase we have made the translation and adaptation processes of the Hungarian form of the OKAT through 5 stages. The translation process from English to Hungarian was based on the process of forward and backward translation. First the forward translation was made by two independent bilingual translators whose native language is Hungarian after the synthesis of the translations was created by us. In the third stage the backward translation and comparison between the Hungarian and English version was completed by two bilingual translators, one of them was a professional medical translator and the other one was an expert of osteoporosis with high advanced English language certification. The fourth stage included an expert committee discussion. Any discrepancy was reviewed by the committee before a final consensus was reached. In the last stage of the translation and adaptation process of the Hungarian version of the instrument was piloted on thirty women to assure comprehension and ease of administration. Few minor changes were made after the pilot testing that has made it easier for everyone to understand. The final Hungarian version of OKAT went for the second phase of this study, which included an assessment of the test-retest 
among a convenience sample of 40 women from September 2018 to October 2018 to examine the reliability of the questionnaire. The participants completed the questionnaire twice with 3 weeks apart. The measurement of the osteoporosis-related knowledge was assessed at baseline from December 2018 to July 2019.

\section{Selection and description of participants}

The total population of Hungary in 2019 was 9,772,756 in the last population census, of which 5,096,935 were women. According to the Hungarian Central Statistical Office the female population was 199,944 in the region (Baranya County) of which, 49,051 were women aged between 25 and 44 years of age [31]. Participants from the region were randomly selected in this age range from the University of Pécs (students and workers) with the Unified Online Registration System, from hospitals (healthcare workers) with the Integrated Clinical Center's nominal roll and from the gyms and fitness rooms (health young women) according to the pass serial numbers.

The main inclusion criteria were apparently healthy women whose native language is Hungarian and who approved to participate in the study. Women were excluded if they had previously had measurement of bone density, thyroid disease, renal failure, malignancy or rheumatoid arthritis, a history of hysterectomy, were on hormone replacement therapy, were pregnant or planning pregnancy within 2 years of study entry or were lactating. Only those women completed the questionnaire anonymously who matched the inclusion criteria, there were no exclusion factors and gave their verbal and written consent after being informed about the aim of the research.

Accordingly, we contacted 600 women, 43 of them did not agree to participate in our examination because of the reasons like "lack of time"; "there is no osteoporosis in my family"; "I am on holiday now". Based on these reasons our sample included 557 premenopausal women between 25 and 44 years from the region with different levels of education and variant professions. The data collection was executed by paper-based and online selfcompleted method.

\section{Technical information}

The OKAT is a questionnaire with 20 items with "true", "false" and "don't know "options. Each item is coded 0 if an incorrect answer or a "don't know" answer is given and 1 if the correct answer was given with a total potential score of twenty. This 20 -item questionnaire focuses on four basic domains: (1) understanding (symptoms and risk of fracture) of osteoporosis (2) the knowledge of risk factors for osteoporosis (3) knowledge of preventive factors as physical activity and diet relating to osteoporosis and (4) treatment availability [30].
Ethics approval was obtained from the Regional Research Ethics Committee of University of Pécs (registration number was 7498-PTE2018). All participants gave written informed consent to participate in the study.

\section{Statistics}

Data were entered into Microsoft Excel and all statistical analyses were performed using SPSS (Version 24). Descriptive analysis was carried out. The data were expressed by mean \pm SD and frequency (\%).

The validity and reliability of the osteoporosis knowledge questionnaire were examined by: The Flesch reading ease, where we tested the readability of the OKAT, the scores range from 0 to 100 and value more than 60 means people can readily understand the document. The index of difficulty was calculated by number of correct responses/total number of responses. Value higher than 0.75 means that question was frequently answered correctly. McNemar's test was used to compare the answers of the OKAT between the test and re-test; thus, to identify non-consistent items. Item discrimination (D-value), which test examine how the items discriminate between patients who have low or high knowledge scores. Itemtotal correlations, the correlation of an item with the remainder of the scale where the coefficient is $<0.20$ was considered poor correlation. We tested the inter-item consistency with Cronbach's alpha coefficient, where values more than 0.7 was considered acceptable.

Furthermore, principal components factor analysis was extracted the factor of OKAT. Using factor analysis for questionnaires with dichotomous items is problematic, our analysis based on prevision studies (OKAT VAL). The sampling adequacy for the analysis was confirmed by Kaiser-Meyer-Olkin test $(\mathrm{KMO}=0.87)$ and Bartlett's test of Sphericity ( $22=1710.88 ; p<0.001)$. EFA was performed through principal component analysis on 20 items and yielded one factors with eigenvalues higher than 1. As the criteria for factor extraction, we applied the factor loading cut off value of 0.30 .

\section{Results}

A total of 557 women were recruited who agreed to participate in the study. The average age of participants was $34.45 \pm 6.92$ years, and there was a wide spread of participants across educational levels history of smoking and alcohol intake. No missing values to any item were reported for the questions (Table 1).

Significant differences $(p<0.001)$ were reported between total scores of OKAT and the age categories. In younger age the knowledge was higher, and it decreased with aging. There were significant differences $(p<0.001)$ in the education levels and between the types of the professions. It was observed that with higher level of education combined with higher level of osteoporosis- 
Table 1 Women's characteristics of the sample $(n=557)$ and the total scores of OKAT examination by variables

\begin{tabular}{|c|c|c|c|c|}
\hline Age & No. of the cases $(n)$ & Percentage (\%) & Mean \pm SD & $P$ value \\
\hline $25-29$ years & 188 & 33.75 & $11.85 \pm 4.32$ & $<0.001$ \\
\hline 30-34 years & 90 & 16.16 & $11.18 \pm 4.15$ & \\
\hline $35-39$ years & 90 & 16.16 & $11.33 \pm 4.33$ & \\
\hline 40-44 years & 189 & 33.93 & $10.03 \pm 4.06$ & \\
\hline \multicolumn{5}{|l|}{ Marital Status } \\
\hline Single / Divorced / Widow & 131 & 23.52 & $10.87 \pm 4.56$ & 0.162 \\
\hline In relationship & 221 & 39.68 & $11.45 \pm 4.18$ & \\
\hline Married & 205 & 36.8 & $10.7 \pm 4.27$ & \\
\hline \multicolumn{5}{|l|}{ Education level } \\
\hline Primary education & 9 & 1.62 & $5.22 \pm 3.42$ & $<0.001$ \\
\hline Secondary school (medical) & 34 & 6.09 & $11.82 \pm 3.19$ & \\
\hline Secondary school (not medical) & 60 & 10.77 & $7.68 \pm 3.84$ & \\
\hline High school & 75 & 13.46 & $9.61 \pm 3.91$ & \\
\hline University (Bs) & 225 & 40.39 & $11.88 \pm 3.81$ & \\
\hline University (Ms) & 140 & 25.13 & $11.74 \pm 4.38$ & \\
\hline University (PhD) & 14 & 2.51 & $14.43 \pm 4.39$ & \\
\hline \multicolumn{5}{|l|}{ Professions } \\
\hline Health care profession & 181 & 32.49 & $14.53 \pm 3.58$ & $<0.001$ \\
\hline Non-health care profession & 376 & 67.50 & $9.99 \pm 4.04$ & \\
\hline \multicolumn{5}{|l|}{ Family history about osteoporosis } \\
\hline With osteoporosis & 270 & 48.47 & $12.08 \pm 4.17$ & $<0.001$ \\
\hline Without osteoporosis & 287 & 51.53 & $10.06 \pm 4.13$ & \\
\hline \multicolumn{5}{|l|}{ Family history of fracture } \\
\hline With fracture & 136 & 24.42 & $13.4 \pm 3.96$ & $<0.001$ \\
\hline Without fracture & 343 & 61.58 & $10.64 \pm 4.04$ & \\
\hline Do not know & 78 & 14.00 & $8.67 \pm 3.94$ & \\
\hline \multicolumn{5}{|l|}{ History of smoking } \\
\hline Do not smoke & 430 & 77.19 & $11.32 \pm 4.04$ & $=0.024$ \\
\hline Average 1 to 5 cigarette per day & 37 & 6.64 & $10.76 \pm 4.36$ & \\
\hline Average 6 to 10 cigarette per day & 45 & 8.08 & $10.4 \pm 5.19$ & \\
\hline Average 10 to 20 cigarette per day & 36 & 6.46 & $8.75 \pm 4.78$ & \\
\hline On average more than 1 box per day & 9 & 1.62 & $11.33 \pm 4.95$ & \\
\hline \multicolumn{5}{|l|}{ Alcohol intake } \\
\hline Never & 83 & 14.90 & $11.19 \pm 4.58$ & $=0.152$ \\
\hline Occasionally (1-2 times a year) & 246 & 44.17 & $11.19 \pm 4.04$ & \\
\hline Every 3 month & 117 & 21.01 & $11.19 \pm 4.14$ & \\
\hline Several times a month & 75 & 13.46 & $10.76 \pm 4.56$ & \\
\hline Weekly & 30 & 5.39 & $10.47 \pm 4.56$ & \\
\hline Several times a week & 6 & 1.08 & $6.17 \pm 2.79$ & \\
\hline \multicolumn{5}{|l|}{ Health promotion (prevention) } \\
\hline I do lot for it & 55 & 9.87 & $12.6 \pm 4.73$ & $<0.001$ \\
\hline I do several things for it & 242 & 43.44 & $11.61 \pm 4.23$ & \\
\hline I do few for it & 221 & 39.68 & $10.49 \pm 3.93$ & \\
\hline I do very few for it & 30 & 5.39 & $9.27 \pm 4.1$ & \\
\hline
\end{tabular}


Table 1 Women's characteristics of the sample $(n=557)$ and the total scores of OKAT examination by variables (Continued)

\begin{tabular}{|c|c|c|c|c|}
\hline Age & No. of the cases $(n)$ & Percentage (\%) & Mean \pm SD & $P$ value \\
\hline I do not care for it & 9 & 1.68 & $5.66 \pm 3.28$ & \\
\hline \multicolumn{5}{|l|}{ Health status } \\
\hline Excellent & 75 & 13.46 & $13.05 \pm 4.25$ & $<0.001$ \\
\hline Very good & 255 & 45.78 & $11.1 \pm 4.03$ & \\
\hline Good & 201 & 36.09 & $10.53 \pm 4.14$ & \\
\hline Fair & 23 & 4.13 & $9 \pm 5.75$ & \\
\hline Poor & 3 & 0.54 & $7.75 \pm 3.5$ & \\
\hline
\end{tabular}

related knowledge. The results were higher in the healthcare professions. Higher osteoporosis-related knowledge was found with osteoporosis and fracture by osteoporosis in the family history furthermore with better health status and promotion the knowledge about osteoporosis was significantly higher (Table 1.)

Significant $(p<0.001)$ correlation was found between the education level $(r=0.25)$ and the osteoporosisrelated knowledge furthermore with the health status $(r=0.18)$ and negative significant $(p<0.001)$ correlation $(r=-0.18)$ with the ages. Based on these with higher level of general education women have higher knowledge about osteoporosis as well as with better knowledge participants have more appropriate health status, over and above appreciable that the osteoporosis-related knowledge is getting worse with aging.

The English version of the OKAT had a Flesch reading ease of 45 , the Hungarian form had almost the same with 44. If the word osteoporosis were removed from the English version questions the reading ease rose to 65, while the Hungarian form rose to 53.

The index of difficulty for most items was satisfactory (between 0.25 and 0.716). Items $1,4,8$ and 15 scored above 0.75 , indicating that most participants answered correctly.

The percentage of correct answers as shown is based on Winzenberg et al. [30], furthermore on the latest European guidance for the diagnosis and management of osteoporosis in postmenopausal women according to Kanis et al. [2] (Table 2.)

The reliability statistics for all the 20 items of the Hungarian version of the OKAT was high, Cronbach's alpha was 0.81 which is excellent, and it is in the acceptability range (0.7-0.85).

The mean D-value (item discrimination) for the questionnaire was $50.4 \%$. Discriminatory power was measured by Ferguson's sigma which was 0.94 for the questionnaire.

According to the item-total correlations psychometric properties of the OKAT, there were no negative interitem correlations. All items had more than $70 \%$ of correlations which were significant $(p<0.001)$ and so were satisfactory (Table 3.)

\section{Discussion}

This study aimed to validate and test the reliability of the Hungarian version of the OKAT, which is the first questionnaire in Hungarian that measures the knowledge about osteoporosis. The questionnaire is developed for premenopausal healthy women between 25 and 44 years. We have made the data collection with 557 women in this age group. No missing values to any item were reported for the questions. The OKAT performed satisfactorily on virtually all components of the analysis.

Cross sectional studies have reported that the levels of osteoporosis knowledge in random, population-based samples are higher in younger ages and higher level of education also defines it $[12,15,32]$. This difference is visible in our study too. We also have found significant difference between total scores of OKAT and the age categories. The osteoporosis-related knowledge was higher with younger age. Significant differences were also found in the knowledge score between the education levels and profession types. The higher the education level was, the greater the knowledge about osteoporosis was confirmed. Several studies have showed that healthcare students and workers osteoporosis-related knowledge is better than non-healthcare workers $[10,12,33]$. In the comparison of the professions the healthcare workers had significantly better knowledge compared to the non-healthcare workers in our study too.

The questionnaire had a Flesch reading ease of 44 which is similar to the original (45) English version [30]. It was due to the word osteoporosis; it is in 12 of the 20 items. If this word was removed the Flesch reading ease became more acceptable. The word osteoporosis was the most accurate description of the disease about which knowledge was being measured and it is widely recognised in the general population.

The index of difficulty for most items was satisfactory because almost every item value was between the optimal 0.25 and 0.716. Items 1 (Osteoporosis leads to an increased risk of bone fractures.), item 4 (Osteoporosis is more common in men.), item 8 (By age 80, the majority of women have osteoporosis.) and item 15 (Calcium supplements alone can prevent bone loss.) scored above 0.75 . 
Table 2 Correct answers for the OKAT among the study sample and at test/re-test sample $(n=40)$

\begin{tabular}{|c|c|c|c|c|c|c|c|}
\hline \multicolumn{7}{|l|}{ Correct answers (\%) } & \multirow{3}{*}{$\begin{array}{l}\text { McNemar's tests } \\
\text { ( } p \text { value) }\end{array}$} \\
\hline & \multicolumn{2}{|c|}{$\begin{array}{l}\text { All }(n= \\
557)\end{array}$} & \multicolumn{2}{|c|}{$\begin{array}{l}\text { Test } \\
(n=40)\end{array}$} & \multicolumn{2}{|c|}{$\begin{array}{l}\text { Retest } \\
(n=40)\end{array}$} & \\
\hline & $\mathbf{N}$ & $\%$ & $\mathbf{N}$ & $\%$ & $\mathbf{N}$ & $\%$ & \\
\hline 1. Osteoporosis leads to an increased risk of bone fractures. & 541 & 95.92 & 38 & 95.00 & 38 & 97.44 & 1.000 \\
\hline 2. Osteoporosis usually causes symptoms (e.g. pain) before fractures occur. & 307 & 54.43 & 17 & 42.50 & 18 & 46.15 & 1.000 \\
\hline $\begin{array}{l}\text { 3. Having a higher peak bone mass at the end of childhood gives no protection against } \\
\text { the development of osteoporosis in later life. }\end{array}$ & 179 & 31.85 & 15 & 37.50 & 17 & 43.59 & 0.375 \\
\hline 4. Osteoporosis is more common in men. & 451 & 79.96 & 31 & 77.50 & 30 & 76.92 & 1.000 \\
\hline 5. Cigarette smoking can contribute to osteoporosis. & 389 & 68.97 & 24 & 60.00 & 26 & 66.67 & 0.250 \\
\hline 6. White women are at highest risk of fracture as compared to other races. & 271 & 48.05 & 24 & 60.00 & 23 & 58.97 & 1.000 \\
\hline 7. A fall is just as important as low bone strength in causing fractures. & 357 & 63.41 & 30 & 75.00 & 28 & 71.79 & 1.000 \\
\hline 8. By age 80 , the majority of women have osteoporosis. & 451 & 79.96 & 33 & 82.50 & 32 & 82.05 & 1.000 \\
\hline 9. From age 50, most women can expect at least one fracture before they die. & 250 & 44.33 & 18 & 45.00 & 17 & 43.59 & 1.000 \\
\hline 10. Any type of physical activity is beneficial for osteoporosis. & 141 & 25.00 & 12 & 30.00 & 11 & 28.21 & 1.000 \\
\hline 11. It is easy to tell whether I am at risk of osteoporosis by my clinical risk factors. & 283 & 50.18 & 24 & 60.00 & 24 & 61.54 & 1.000 \\
\hline 12. Family history of osteoporosis strongly predisposes a person to osteoporosis. & 404 & 71.63 & 32 & 80.00 & 31 & 79.49 & 1.000 \\
\hline 13. An adequate calcium intake can be achieved from two glasses of milk a day. & 312 & 55.32 & 23 & 57.50 & 22 & 56.41 & 1.000 \\
\hline $\begin{array}{l}\text { 14. Sardines and broccoli are good sources of calcium for people who cannot take } \\
\text { dairy products. }\end{array}$ & 350 & 62.17 & 27 & 67.50 & 28 & 71.79 & 0.500 \\
\hline 15. Calcium supplements alone can prevent bone loss. & 426 & 75.53 & 32 & 80.00 & 31 & 79.49 & 1.000 \\
\hline 16. Alcohol in moderation has little effect on osteoporosis. & 221 & 39.18 & 17 & 42.50 & 17 & 43.59 & 1.000 \\
\hline 17. A high salt intake is a risk factor for osteoporosis. & 160 & 28.47 & 14 & 35.00 & 16 & 41.03 & 0.500 \\
\hline $\begin{array}{l}\text { 18. There is a small amount of bone loss in the ten years following the onset of } \\
\text { menopause. }\end{array}$ & 304 & 54.00 & 14 & 35.00 & 15 & 38.46 & 1.000 \\
\hline 19. Hormone therapy prevents further bone loss at any age after menopause. & 131 & 23.27 & 8 & 20.00 & 6 & 15.38 & 1.000 \\
\hline 20. There are no effective treatments for osteoporosis available in "Hungary"a. & 296 & 52.48 & 21 & 52.50 & 20 & 51.28 & 1.000 \\
\hline
\end{tabular}

a Originally Australia

This fact indicating that these four questions were easy to answer and most of the participants answered them correctly.

The mean D-value, that measures the item discrimination for the questionnaire was $50.4 \%$. Discriminatory power for the questionnaire was measured by Ferguson's sigma what was close to the ideal value of 1.0 with the value 0.94 . Though factor analysis must be interpreted cautiously when analysing dichotomous variables, the fact that the analysis did not generate factor with an eigenvalue above 1 is consistent with osteoporosis knowledge being the main factor being measured by the questionnaire. This provides some support for the construct validity of the instrument.

The Hungarian version of OKAT showed consistent findings between the test and retest results. The Cronbach's alpha of the original English version was 0.69, which was satisfactory for the authors. In our study the Hungarian version got excellent 0.81 that is in the acceptability range $(0.7-0.85)$. The OKAT must include very easy items as well as very difficult items, which tends to decrease the internal consistency of the scale Cronbach's alpha.
In developed countries, including the Central European countries, like Hungary the prevalence and incidence of osteoporosis is significantly high due to the technical development and the increasing expected lifetime. The prevention should take bigger role in increasing the osteoporosis-related knowledge in order to maintain the osteoporosis preventive behaviours namely raising the level of the physical activity and the intake of adequate calcium and vitamin $\mathrm{D}$ in the ages when the disease can be preventable [34].

The Hungarian version of the OKAT is the first questionnaire that can measures the knowledge in young Hungarian-speaking women. The Hungarian version of the OKAT covers the core of osteoporosis-related knowledge; it can be useful in further follow up studies to measure the effectiveness of the preventable education programs.

\section{Limitations}

However, the results confirmed that OKAT is a valid and reliable tool to examine the Hungarian population's osteoporosis-related knowledge, the study has a number 
Table 3 Psychometric Properties of the OKAT by Item

\begin{tabular}{|c|c|c|c|c|}
\hline Item Number & $\begin{array}{l}\text { Item } \\
\text { Discrimination } \\
\text { (\%) }\end{array}$ & $\begin{array}{l}\text { Item-total } \\
\text { correlation }\end{array}$ & $\begin{array}{l}P \\
\text { value }\end{array}$ & $\begin{array}{l}\text { Factor } \\
\text { Loading }\end{array}$ \\
\hline 1. Osteoporosis leads to an increased risk of bone fractures. & 12.42 & 0,7 & $\begin{array}{l}< \\
0.001\end{array}$ & 0.61 \\
\hline 2. Osteoporosis usually causes symptoms (e.g. pain) before fractures occur. & 58.33 & 0.85 & $\begin{array}{l}< \\
0.001\end{array}$ & 0.47 \\
\hline $\begin{array}{l}\text { 3. Having a higher peak bone mass at the end of childhood gives no protection against } \\
\text { the development of osteoporosis in later life. }\end{array}$ & 78.42 & 1.00 & $\begin{array}{l}< \\
0.001\end{array}$ & 0.45 \\
\hline 4. Osteoporosis is more common in men. & 46.35 & 0.94 & $\begin{array}{l}< \\
0.001\end{array}$ & 0.56 \\
\hline 5. Cigarette smoking can contribute to osteoporosis. & 44.95 & 0.83 & $\begin{array}{l}< \\
0.001\end{array}$ & 0.43 \\
\hline 6. White women are at highest risk of fracture as compared to other races. & 66.67 & 1.00 & $\begin{array}{l}< \\
0.001\end{array}$ & 0.43 \\
\hline 7. A fall is just as important as low bone strength in causing fractures. & 34.71 & 1.00 & $\begin{array}{l}< \\
0.001\end{array}$ & 0.72 \\
\hline 8. By age 80 , the majority of women have osteoporosis. & 51.61 & 0.84 & $\begin{array}{l}< \\
0.001\end{array}$ & 0.47 \\
\hline 9. From age 50, most women can expect at least one fracture before they die. & 45.05 & 0.89 & $\begin{array}{l}< \\
0.001\end{array}$ & 0.52 \\
\hline 10. Any type of physical activity is beneficial for osteoporosis. & 62.38 & 0.95 & $\begin{array}{l}< \\
0.001\end{array}$ & 0.48 \\
\hline 11. It is easy to tell whether I am at risk of osteoporosis by my clinical risk factors. & 41.76 & 0.89 & $\begin{array}{l}< \\
0.001\end{array}$ & 0.48 \\
\hline 12. Family history of osteoporosis strongly predisposes a person to osteoporosis. & 41.47 & 0.91 & $\begin{array}{l}< \\
0.001\end{array}$ & 0.45 \\
\hline 13. An adequate calcium intake can be achieved from two glasses of milk a day. & 53.69 & 0.85 & $\begin{array}{l}< \\
0.001\end{array}$ & 0.66 \\
\hline $\begin{array}{l}\text { 14. Sardines and broccoli are good sources of calcium for people who cannot take dairy } \\
\text { products. }\end{array}$ & 58.99 & 0.74 & $\begin{array}{l}< \\
0.001\end{array}$ & 0.39 \\
\hline 15. Calcium supplements alone can prevent bone loss. & 50.54 & 1.00 & $\begin{array}{l}< \\
0.001\end{array}$ & 0.38 \\
\hline 16. Alcohol in moderation has little effect on osteoporosis. & 39.04 & 0.87 & $\begin{array}{l}< \\
0.001\end{array}$ & 0.71 \\
\hline 17. A high salt intake is a risk factor for osteoporosis. & 42.22 & 1.00 & $\begin{array}{l}< \\
0.001\end{array}$ & 0.56 \\
\hline $\begin{array}{l}\text { 18. There is a small amount of bone loss in the ten years following the onset of } \\
\text { menopause. }\end{array}$ & 47.65 & 1.00 & $\begin{array}{l}< \\
0.001\end{array}$ & 0.42 \\
\hline 19. Hormone therapy prevents further bone loss at any age after menopause. & 70.12 & 0.95 & $\begin{array}{l}< \\
0.001\end{array}$ & 0.49 \\
\hline 20. There are no effective treatments for osteoporosis available in "Hungary"a . & 62.33 & 0.95 & $\begin{array}{l}< \\
0.001\end{array}$ & 0.45 \\
\hline
\end{tabular}

${ }^{a}$ Originally Australia

of potential limitations. The sample was randomly selected, but selection bias is possible due to the moderate response rate. By ages, we have created four categories (25-29 years; 30-34 years; 35-39 years; 40-44 years). In the first category (33.75\%) and in the fourth (33.93\%) the number of the participants was significantly higher, than in the other two categories that could also influence the results. However, our sample was quite big there were only few women with basic primary education, while the number of the participants with Bs and Ms. Degree were quite high.

\section{Conclusion}

This study's aim was to validate the OKAT Hungarian form in a randomly selected sample. Based on the results we achieved the Hungarian version of the OKAT is a reliable and objective method to measure women's knowledge in Hungary between 25 and 44 years. Further research is needed with a representative sample to measure the osteoporosis-related knowledge with this tool to get normal values for the Hungarian population. 


\section{Acknowledgements}

Not applicable.

\section{About this supplement}

This article has been published as part of BMC Public Health Volume 21 Supplement 1, 2021: Level and Determinants of Physical Activity in the V4 Countries - Part 2. The full contents of the supplement are available online at URL. https://bmcpublichealth.biomedcentral.com/articles/supplements/ volume-21-supplement-1.

\section{Authors' contributions}

All authors read and approved the final manuscript. PT, MJ and BSZ conceived, designed and managed the study, PÁ, BM and MH contributed to the study conceptualization and provided critical editorial input to the interpretation of the data, AM contributed in statistical analysis, PT, MJ, BSZ, MGY and AM contributed to data collection, to the drafting and final editing of the manuscript.

\section{Funding}

The publication costs were funded by the Economic Development and Innovation Operational Programme GINOP 2.3.2-15-2016-00047 grant. The authors declare that the design of the study and collection, analysis, and interpretation of data and writing of the manuscript are independent of GINOP.

\section{Availability of data and materials}

All data generated or analysed during this study are included in this published article [and its supplementary information files].

\section{Ethics approval and consent to participate}

Ethics approval was obtained from the Regional Research Ethics Committee of University of Pécs (registration number was 7498-PTE2018). All participants gave written informed consent to participate in the study.

\section{Consent for publication}

Not applicable.

\section{Competing interests}

The authors declare that they have no conflict of interest.

\section{Author details}

'University of Pécs, Faculty of Health Sciences, Institute of Physiotherapy and Sport Science, Pécs, Hungary. ${ }^{2}$ University of Pécs, Faculty of Health Sciences, Doctoral School of Health Sciences, Pécs, Hungary. ${ }^{3}$ University of Pécs, Faculty of Health Sciences, Institute of Health Insurance, Pécs, Hungary.

Received: 31 January 2021 Accepted: 1 February 2021 Published: 23 April 2021

\section{References}

1. Kanis JA, et al. Executive summary of the European guidance for the diagnosis and management of osteoporosis in postmenopausal women. Calcif Tissue Int. 2019:104(3):235-8.

2. Kanis JA, et al. European guidance for the diagnosis and management of osteoporosis in postmenopausal women (vol 30, pg 3, 2019). Osteoporos Int. 2020;31(4):801

3. Albayrak I, et al. The association between bone mineral density, quality of life, quality of sleep and fatigue. Acta Clin Belg. 2016;71(2):92-8.

4. Miyakoshi $N$, Kudo D, Hongo M, Kasukawa $Y$, Ishikawa $Y$, Shimada $Y$. Comparison of spinal alignment, muscular strength, and quality of life between women with postmenopausal osteoporosis and healthy volunteers. Osteoporos Int. 2017;28(11):3153-60.

5. Ciubean AD, Ungur RA, Irsay L, Ciortea VM, Borda IM, Onac L, Vesa SC, Buzoianu AD. Health-related quality of life in Romanian postmenopausal women with osteoporosis and fragility fractures. Clin Interv Aging. 2018;13 2465-72.

6. Kerr C, Bottomley C, Shingler S, Giangregorio L, de Freitasi HM, Patel C, Randall S, Gold DT. The importance of physical function to people with osteoporosis. Osteoporos Int. 2017;28(5):1597-607.
7. Pisani P, Renna MD, Conversano F, Casciaro E, Di Paola M, Quarta E, Muratore M, Casciaro S. Major osteoporotic fragility fractures: Risk factor updates and societal impact. World J Orthop. 2016;7(3):171-81.

8. Wright NC, et al. The recent prevalence of osteoporosis and low bone mass in the United States based on bone mineral density at the femoral neck or lumbar spine. J Bone Miner Res. 2014;29(11):2520-6.

9. HCSO. The European health interview survey (Európai Lakossági Egészségfelmérés). Statisztikai Tükör. 2014;2015(29):1-9.

10. Sayed-Hassan R, Bashour H, Koudsi A. Osteoporosis knowledge and attitudes: a cross-sectional study among female nursing school students in Damascus. Arch Osteoporos. 2013;8(1-2):149-56.

11. Bilal $M$, et al. Knowledge, beliefs and practices regarding osteoporosis among female medical school entrants in Pakistan. Asia Pac Fam Med. 2017:16:6

12. Darout IA, Alamir A, Sultana S. Osteoporosis Knowledge and related health behavior among women in Jazan region, Kingdom of Saudi Arabia. J Contemp Dent Pract. 2017;18(5):378-82

13. Senthilraja M, et al. Osteoporosis knowledge and beliefs among postmenopausal women: a cross-sectional study from a teaching hospital in southern India. J Fam Med Prim Care. 2019:8(4):1374-8.

14. Tabor $E$, et al. The relationship of Knowledge of osteoporosis and bone health in postmenopausal women in Silesia Osteo active study. J Clin Densitom. 2018;21(1):98-104

15. Al-Otaibi HH. Osteoporosis health beliefs, knowledge and life habits among women in Saudi Arabia. Open J Prev Med. 2015;5(6):236-43.

16. Ács $P$, et al. Economic and public health benefits: the result of increased regular physical activity. Eur J Integr Med. 2016;8(2 Suppl):8-12.

17. Ács $P$, et al. Changes of sport and physical activity indicators in Hungary and in the European Union according to the results from recent years (A sporttal, testmozgással összefüggésben lévő mutatók változása Magyarországon és az Európai Unióban az elmúlt évek eredményeinek nyomán). Sport- és Egészségtudományi Füzetek. 2018;2(1):61-76.

18. Hock M, Takács K, Figler M. Sarcopenia and exercise as determinants of well-being in elderly. J Proactive Med. 2015;3(1):5-10.

19. Makai $A$, et al. The effect of a community-based e-health program to promote the role of physical activity among healthy adults in Hungary. BMC Public Health. 2020. S20(\&). https://doi.org/10.1186/s12889-020-08750-1.

20. Chan CY, et al. Knowledge, Beliefs, Dietary, and Lifestyle Practices Related to Bone Health among Middle-Aged and Elderly Chinese in Klang Valley, Malaysia. Int J Environ Res Public Health. 2019;16(10):1787-806.

21. El Hage C, et al. Osteoporosis awareness and health beliefs among Lebanese women aged 40 years and above. Osteoporos Int. 2019;30(4):771-86.

22. Hallit $\mathrm{S}$, et al. Construction and validation of the Lebanese osteoporosis Knowledge scale among a representative sample of Lebanese women. Osteoporos Int. 2020;31(2):379-89.

23. Ciaschini PM, et al. Community based intervention to optimize osteoporosis management: randomized controlled trial. BMC Geriatr. 2010;10(60). https:// doi.org/10.1186/1471-2318-10-60.

24. Evenson AL, Sanders GF. Educational intervention impact on osteoporosis Knowledge, health beliefs, self-efficacy, dietary calcium, and vitamin D intakes in young adults. Orthop Nurs. 2016;35(1):30-6.

25. Gaines JM, Narrett M, Parrish JM. The effect of the addition of osteoporosis education to a bone health screening program for older adults. Geriatr Nurs. 2010;31(5):348-60.

26. Nielsen $D$, et al. Patient education in groups increases knowledge of osteoporosis and adherence to treatment: a two-year randomized controlled trial. Patient Educ Couns. 2010;81(2):155-60.

27. Malak MZ, Toama ZT. The effect of osteoporosis health education program based on health belief model on knowledge and health beliefs towards osteoporosis among Jordanian female teachers. Eur Sci J. 2015:11(3):385-98.

28. Ghaffari $\mathrm{M}$, et al. Osteoporosis-related knowledge among students of a medical sciences university in Iran: calcium intake and physical activity. Med Life. 2015:8(Spec Iss 4):203-8.

29. Ishtaya GA, et al. Osteoporosis knowledge and beliefs in diabetic patients: a cross sectional study from Palestine. BMC Musculoskelet Disord. 2018;19(1): 43-50.

30. Winzenberg TM, et al. The design of a valid and reliable questionnaire to measure osteoporosis knowledge in women: the osteoporosis Knowledge assessment tool (OKAT). BMC Musculoskelet Disord. 2003;4. https://doi.org/ 10.1186/1471-2474-4-17

31. HCSO. Population census: Regional data - Baranya county. 2019. [Accessed 202010 February]; Available from: https://www.ksh.hu/?lang=en. 
32. Aslan G, Kilic D. Osteoporosis health belief, knowledge level and risk factors in individuals whose bone mineral density is required. Belitung Nurs J. 2017; 3:162-73.

33. Elnaem $\mathrm{MH}$, et al. Osteoporosis Knowledge among future healthcare practitioners: findings from a Malaysian Public University. J Pharm Bioallied Sci. 2017:9(2):115-20

34. Musaiger AO, Al-Hazzaa HM. Prevalence and risk factors associated with nutrition-related noncommunicable diseases in the eastern Mediterranean region. Int J Gen Med. 2012;5:199-217.

\section{Publisher's Note}

Springer Nature remains neutral with regard to jurisdictional claims in published maps and institutional affiliations.

Ready to submit your research? Choose BMC and benefit from:

- fast, convenient online submission

- thorough peer review by experienced researchers in your field

- rapid publication on acceptance

- support for research data, including large and complex data types

- gold Open Access which fosters wider collaboration and increased citations

- maximum visibility for your research: over $100 \mathrm{M}$ website views per year

At BMC, research is always in progress.

Learn more biomedcentral.com/submissions 